\title{
Infectious Hidradenitis
}

National Cancer Institute

\section{Source}

National Cancer Institute. Infectious Hidradenitis. NCI Thesaurus. Code C128428.

Hidradenitis that is caused by an infectious agent, usually a bacterium. 